\title{
Konseling Karir Virual untuk Meningkatkan Kematangan Karir Kelas XII di Masa Pandemi
}

\author{
Komarudin ${ }^{1}$ and Ade Putranto Prasetyo Wijiharto Tunggali ${ }^{2 *}$ \\ 1 Psikologi, Universitas Aisyiyah Yogyakarta, Sleman, 55292, Yogyakarta, Indonesia \\ 2 Ilmu Komunikasi, Universitas Aisyiyah Yogyakarta, Sleman, 55292, Yogyakarta, Indonesia
}

\begin{abstract}
Abstrak. Kematangan karir pada siswa biasanya dihubungkan dengan kesiapan memasuki perguruan tinggi, pengetahuan tentang pilihan program studi di perguruan tinggi, pengetahuan tentang dunia pekerjaan, dan informasi-informasi yang berkaitan dengan dunia perguruan tinggi dan pekerjaan lainnya. Kondisi yang tidak menentu akibat Covid-19 ini menjadikan siswa memiliki kebingungan dalam menentukan kariernya, sehingga menjadikan siswa memiliki kematangan karir yang rendah. Padahal sangat penting bagi siswa memiliki kematangan dalam karirnya, karena hal tersebut berkaitan erat dengan karir masa depan siswa itu sendiri. Kondisi ketidakmatangan karir ini tampak pada beberapa siswa SMA Kelas XII SMA Negeri 1 Sedayu yang ditandai dengan tidak percaya diri dengan kemampuan yang dimiliki untuk melanjutkan ke perguruan tinggi, masih bingung untuk menentukan jurusan kuliah yang cocok dengan kemampuan yang dimiliki, masih ragu untuk melanjutkan kuliah karena kondisi perekonomian kedua orangtuanya yang menurun terdampak pandemi Covid-19. Di lain sisi, siswa-siswa tersebut juga sangat khawatir jika ingin bekerja tidak adanya lowongan kerja setelah lulus karena maraknya PHK. Oleh karena itu, ketidakmatangan karir ini perlu diatasi melalui program "Konseling Karir Virtual Untuk Meningkatkan Kematangan Karir Siswa Kelas XII Sma Negeri 1 Sedayu Di Masa Pandemi Covid-19". Konseling karir secara luas digunakan untuk mengatasi masalah yang dihadapi siswa sehingga performance belajarnya prima. Sementara tujuan spesifik konseling karir adalah membantu siswa mengambil keputusan berkaitan dengan pilihan-pilihan karir setalah lulus SMA. Sementara itu, dipilinnya media virtual ini karena menurut Connolly \& Stansfield (2006), saat ini penerapan teknologi dalam pendidikan telah memasuki generasi keenam, yang merupakan generasi ketiga dari e-learning. Generasi ini dikembangkan lingkungan belajar yang lebih kolaboratif yang didasarkan pada epistimologi konstruktivisme yang mendorong praktek refleksi melalui alat-alat seperti e-portfolio dan onlinecommunities. Luaran dari kegiatan pengabdian kepada masyarakat adalah artikel ilmiah dan video konseling karier.
\end{abstract}

Keywords: Layanan Konseling, Karir Development, Virtual, Pandemi Covid-19,

\section{Pendahuluan}

\subsection{Analisis Situasi}

Pandemi Covid-19 yang muncul di awal tahun 2020 menghantam seluruh aspek

* Corresponding author: komarudin_psi@unisayogya.ac.id

Received 17 October 2021; Received in revised form 26 October 2021; Accepted 26 October 2021

Available online 29 December 2021

Lembaga Penelitian dan Pengabdian Kepada Masyarakat

Universitas Lampung 
kehidupan masyarakat di dunia, tidak terkecuali pada sektor pendidikan. Penutupan sementara sekolah dan lembaga pendidikan sebagai suatu upaya untuk menahan laju penyebaran virus Covid-19 terjadi di hampir seluruh penjuru dunia, termasuk di Indonesia. Berbagai upaya dilakukan pemerintah Indonesia supaya kegiatan belajar tetap dapat berjalan, yaitu menerapkan sistem belajar dari rumah. Kebijakan belajar dari rumah sebagai bentuk respon cepat dari pandemic covid-19 ini tentulah menimbulkan berbagai permasalahan, seperti pembelajaran siswa, gangguan dalam penilaian, pembatalan penilaiaan, peluang mendapatkan pekerjaan setelah lulus, pembatalan penilaian publik untuk kualifikasi dalam seleksi pekerjaan. Kondisi pasar kerja yang cenderung sulit merupakan kendala baru bagi para lulusan di tengah resesi global [1].

Kondisi yang tidak menentu akibat Covid-19 ini menjadikan siswa memiliki kebingungan dalam menentukan kariernya, sehingga menjadikan siswa memiliki kematangan karir yang rendah. Kematangan karir pada peserta didik biasanya dihubungkan dengan kesiapan memasuki perguruan tinggi, pengetahuan tentang pilihan program studi di perguruan tinggi, pengetahuan tentang dunia pekerjaan, dan informasi-informasi yang berkaitan dengan dunia perguruan tinggi dan pekerjaan lainnya. Sangat penting bagi peserta didik memiliki kematangan dalam karirnya, karena hal tersebut berkaitan erat dengan karir masa depan peserta didik itu sendiri [2].

Kondisi ketidakmatangan karir pada diri siswa ini ditemui di SMA N 1 Sedayu Bantul. Berdasarkan pemaparan dari guru BK, adanya pandemi Covid-19 membuat siswa kelas 12 saat ini merasa kebingungan menentukan arah tujuannya setelah lulus SMA. Banyak yang tidak percaya diri dengan kemampuan yang dimiliki karena selama belajar di rumah ini banyak pengetahuan yang dirasa kurang siswa dapatkan, sehingga takut bersaing untuk masuk ke Perguruan Tinggi Negeri. Adapula siswa yang juga masih kebingungan untuk menentukan jurusan kuliah yang cocok dengan kemampuan dirinya. Sementara itu, banyak yang masih ragu untuk melanjutkan kuliah karena kondisi perekonomina kedua orangtuanya yang menurun terdampak pandemi Covid-19. Di lain sisi, siswa - siswa tersebut juga sangat khawatir jika ingin bekerja, sementara banyak perusahaan atau kantor yang memberhentikan karyawannya (PHK).

Rendahnya kematangan karir pada diri siswa kelas 12 ini penting untuk segera diatasi karena berkaitan erat dengan karir masa depan yang akan dijalani oleh siswa. Kondisi wabah Covid-19 yang belum jelas berakhirnya jangan sampai menjadikan siswa memiliki masa depan suram (madesu). Oleh sebab itu, selaku tim dosen pengabdian kepada masyarakat menawarkan program solutif dengan judul "Konseling Karir Virtual Untuk Meningkatkan Kematangan Karir Siswa Kelas XII Sma Negeri 1 Sedayu Di Masa Pandemi Covid-19". Program ini memungkinkan untuk dilaksanakan dengan tetap mempertimbangkan protokol Kesehatan pencegahan penyebaran virus Covid-19, yaitu melalui kegiatan daring / online.

\subsection{Permasalahan Mitra}

Dalam pengabdian kepada masyarakat ini bermitra dengan SMA Negeri 1 Sedayu. Adapun beberapa hal yang menjadi permasalahan mitra berdasarkan hasil wawancara pendahuluan, antara lain:

1) Siswa kelas XII memiliki kematangan karir rendah, yang ditunjukkan dengan masih kebingungan menentukan pilihan karirnya setelah lulus SMA, apakah akan melanjutkan kuliah atau bekerja di dalam masa pandemi Covid-19. 
2) Siswa memiliki keterbatasan untuk memperoleh informasi terkait pilihan karir di masa pandemi Covid-19.

3) Guru BK tidak dapat melakukan layanan konseling secara tatap muka di masa pandemi Covid-19, sehingga memerlukan mitra untuk menjembatani siswa mengakses berbagai informasi pilihan karir melalui media virtual

\subsection{Tujuan Kegiatan}

Berdasarkan data dan permasalahan yang telah diuraikan, maka perlu solusi yang tepat dalam menangani permasalahan mitra. Solusi yang ditawarkan oleh tim dosen pengabdian kepada masyarakat, yaitu "Konseling Karir Virtual Untuk Meningkatkan Kematangan Karir Siswa Kelas XII SMA Negeri 1 Sedayu Di Masa Pandemi Covid-19”.

Menurut Hediarni (2009), konseling karir memiliki dua peran utama, yaitu dalam arti luas dan tujuan spesifik [3]. Dalam arti luas konseling karir digunakan untuk mengatasi masalah yang dihadapi klien sehingga dapat memiliki performance yang prima. Dalam hal ini, siswa SMA Sedayu memiliki kematangan karir yang rendah, sehingga performance yang ditunjukkan dari motivasi belajarnya selama masa pandemi Covid-19 ini juga rendah. Oleh sebab itu, dengan berupaya meningkatkan kematangan karirnya diharapkan motivasi belajar siswa juga akan lebih baik. Sementara tujuan spesifik konseling karir adalah membantu seseorang mengambil keputusan berkaitan dengan pilihan - pilihan karir, sehingga melalui program ini tim dosen akan membantu siswa dalam menentukan pilihan karir melalui media yang interaktif / yaitu media virtual. Dipilihnya media virtual ini karena menurut Connolly \& Stansfield (2006), saat ini penerapan teknologi dalam pendidikan telah memasuki generasi keenam, yang merupakan generasi ketiga dari e-learning [4]. Generasi ini dikembangkan lingkungan belajar yang lebih kolaboratif yang didasarkan pada epistimologi konstruktivisme yang mendorong praktek refleksi melalui alat-alat seperti $e$ portfolio dan online-communities.

Pembelajaran virtual ini memanfaatkan internet sebagai alat bantu utamanya. Pembelajaran dengan memanfaatkan Internet akan mendorong tumbuhnya keterampilan belajar siswa (learning how to learn), keterampilan bernalar (higher order thinking skills), keterampilan berkomunikasi (lisan dan tertulis), kemampuan menemukan beragam sumber belajar, meningkatkan keaktifan siswa, serta meningkatkan keterampilan sosial [5]. Lebih lanjut Anderson (2006) mengemukakan bahwa dengan memberikan kesempatan kepada siswa untuk berinteraksi dengan berbagai sumber belajar yang tersedia melaui Internet, keterampilan siswa dalam belajar sepanjang hayat akan meningkat [6]. Selain itu, melalui diskusi online siswa akan menguasai keterampilan komunikasi yang bertanggung jawab dan profesional.

Tabel 1. Gambaran prioritas permasalahan, solusi permasalahan dan target luaran

\begin{tabular}{clcl}
\hline No & Prioritas permasalahan mitra & Solusi permasalahan & \multicolumn{1}{c}{ Target luaran } \\
\hline $\begin{array}{l}\text { Kematangan Karir Siswa Kelas } \\
\text { XII SMA Negeri 1 Sedayu Di } \\
\text { Masa Pandemi Covid-19 }\end{array}$ & Konseling Karier Virtual & $\begin{array}{l}\text { Video konseling karier virtual } \\
\text { dan artikel ilmiah }\end{array}$ \\
\hline
\end{tabular}

\section{Metode}

Metode kegiatan ini meliputi ceramah, diskusi, focus group discussion, pendekatan menggunakan audio dan video serta evaluasi pelaksanaan. Materi ceramah didasarkan pada materoi utama yaitu kematangan karir, dilanjutkan dengan talkshow menggunakan channel youtube secara virtual dan dilakikan evaluasi pelaksanaan kegiatan yang terdiri dari 
evaluasi awal, proses dan evaluasi akhir

\subsection{Metode dan Tahapan Kegiatan}

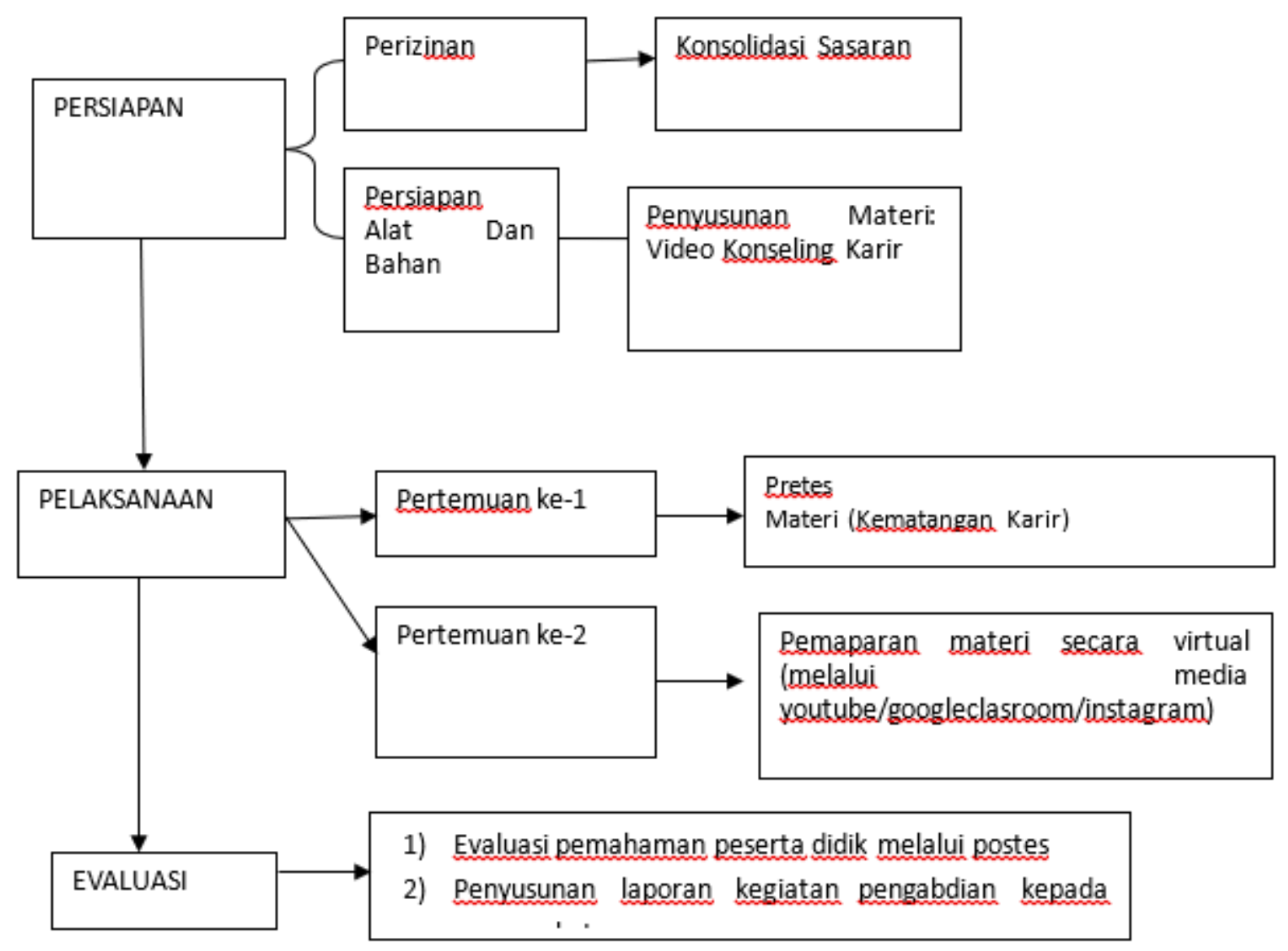

Gambar 1. Alur pelaksanaan program

\subsection{Deskripsi Kegiatan}

Metode pelaksanaan program pengabdian kepada masyarakat dengan judul "Konseling Karir Virtual Untuk Meningkatkan Kematangan Karir Siswa Kelas XII Sma Negeri 1 Sedayu Di Masa Pandemi Covid-19", yang diuraikan sebagai berikut:

\subsubsection{Persiapan}

Pada tahap ini, kegiatan yang dilakukan yaitu mengurus perizinan dalam melakukan pengabdian masyarakat, melakukan konsolidasi dengan sasaran, serta penyusunan materi dan persiapan alat bahan untuk kegiatan.

a. Perizinan

Perizinan dalam hal ini berkenaan dengan kesediaan mitra, yaitu guru koordinator BK SMA 1 Sedayu untuk dijadikan sebagai mitra dalam pelaksanaan pengabdian kepada masyarakat.

b. Konsolidasi dengan sasaran

Konsolidasi dengan sasaran (guru koordinator BK dan siswa SMA 1 Sedayu) dimaksudkan untuk memperkuat hubungan mitra kerjasama yang telah terwujud melalui perizinan dan juga mendiskusikan mengenai teknis pelaksanaan pengabdian kepada masyarakat. 
C. Penyusunan materi

Berdasarkan hasil konsolidasi, kemudian disusun materi yang akan digunakan dalam dalam bentuk video konseling karir yang terdiri dari video Mengenali Potensi Diri dan Strategi Menentukan Pilihan Karir

d. Persiapan alat dan bahan

Persiapan berbagai alat dan bahan yang mendukung pelaksanaan psikoedukasi yaitu:

1) Pembuatan video konseling karir

2) Pengadaan media pembelajaran, berupa youtube/instagram/google clasroom

\subsubsection{Pelaksanaan Konseling Virtual}

a. Tahap Persiapan Konseling Karir Virtual.

Hal-hal yang perlu dipersiapkan sebelum diselenggarakannya konseling virtual, adalah sebagai berikut:

1) Kuota dan jaringan internet

2) Laptop

3) Alat live streaming (microphone, headset, kamera dll)

4) Daftar hadir peserta melalui google form

5) Video materi konseling karir

b. Tahap Pelaksanaan Konseling Karir Virtual

1) Pertemuan pertama, yaitu: perkenalan, pretest (kematangan karir), pemberian materi "Mengenal Potensi Diri" melalui live streaming

2) Pertemuan kedua, yaitu: pemberian materi "Strategi Menentukan Pemilihan Karir" melalui live streaming

c. Evaluasi yang dilakukan yaitu:

1) Evaluasi pelaksanaan pelatihan berdasarkan hasil postest.

2) Penyusunan laporan kegiatan program pengabdian kepada masyarakat.

Tabel 2. Gambaran partisipasi mitra, evaluasi dan keberlanjutan program

\begin{tabular}{|c|c|c|c|}
\hline No & Nama Kegiatan & Partisipasi mitra & $\begin{array}{l}\text { Evaluasi dan keberlanjutan } \\
\text { program }\end{array}$ \\
\hline 1 & Persiapan & $\begin{array}{l}\text { Memberikan perizinan, memberikan } \\
\text { akses media sosial sekolah }\end{array}$ & $\begin{array}{l}\text { Memperoleh perizinan untuk } \\
\text { melaksanakan program pengabdian } \\
\text { dan akses masuk ke media sosial } \\
\text { sekolah }\end{array}$ \\
\hline 2 & Pelaksanaan & $\begin{array}{l}\text { Berkolaborasi dalam memberikan } \\
\text { konseling virtual melalui video }\end{array}$ & $\begin{array}{l}\text { Dapat melaksanakan kegiatan } \\
\text { melalui google classroom kelas XII }\end{array}$ \\
\hline 3 & Evaluasi & Fasilitasi pretest dan postest & $\begin{array}{l}\text { Dapat diukur efektifitas kegiatan } \\
\text { sebagai bukti ilmiah }\end{array}$ \\
\hline
\end{tabular}

\subsection{Evaluasi}

Dalam mengevaluasi kegiatan pengabdian kepada masyarakat ini dibagi menjadi tiga tahap yaitu:

1. Evaluasi awal (pre-test), dengan memberikan test yang berupa daftar pertanyaan (kuisioner), dilakukan sebelum kegiatan penyampaian materi.

2. Evaluasi proses, dilakukan untuk menilai keadaan selama kegiatan pelatihan berlangsung. Evaluasi ini dilakukan untuk setiap komponen yang berhubungan 
langsung dengan kegiatan dalam program pelatihan. Sebagai indikator utama dalam kegiatan evaluasi proses meliputi kehadiran dan perhatian, serta aktivitas dan tanggapan peserta selama kegiatan berlangsung.

3. Evaluasi akhir (post-test), dengan memberikan test yang berupa daftar pertanyaan (kuisioner), dilakukan setelah kegiatan penyampaian materi, diskusi.

\section{Hasil dan Pembahasan}

Berdasarkan hasil analisa terhadap angket Kematangan karir yang diberika setelah peserta menyaksikan video Pengabdian Masyarakat dengan tema Konseling Karir Virtual Untuk Meningkatkan Kematangan Karir Siswa Kelas XII SMA Negeri 1 Sedayu Di Masa Pandemi Covid-19, menghasilkan beberapa hal sebagai berikut:

1. Meningkatkan pemahaman peserta, bahwa pendidikan adalah investasi bagi masa depan dan mereka percaya bahwa kuliah bukan untuk status melainkan tentang bidang keilmuan yang sesuai dengan minat dan bakat yang dimiliki.

2. Peserta juga memahami dengan potensi yang dimilikinya dan melanjutkan studi sesuai dengan bakat dan minat, bukan karena pilihan orangtua semata.

3. Meskipun demikian peserta kurang percaya untuk mengatasi masalah sendiri dalam memutuskan sesuatu, sehingga ketika memilih jurusan program studi di Perguruan Tinggi, mereka berdiskusi dengan orangtua terlebih dahulu. Dalam proses pemilihan karir, Sebagian besar peserta terbuka terhadap kritikan dan pendapat dari orang lain.

4. Akan tetapi ada nilai yang kurang baik dimiliki oleh Sebagian besar peserta, yaitu mereka takut untuk berkompetisi dengan orang lain. Berdasarkan penggalian lebih lanjut kepada beberapa peserta, adanya kurang percaya diri ini karena menganggap bahwa sekolah mereka adalah sekolah pinggiran dan ada ketakutan bersaing dengan sekolah yang ada di kota.

\section{Kesimpulan dan Saran}

Dalam kegiatan pengabdian kepada masyarakat ini dapat terlaksana dengan penuh tantangan karena adanya wabah pandemic Covid-19. Pengabdian kepada masyarakat ini memberikan arti positif kepada pihak sekolah khususnya karena perguruan tinggi bersedia berbagi ilmu dan informasi penting kepada siswa - siswi kelas XII yang saat ini sedang bersiap memantapkan diri untuk masuk ke Perguruan Tinggi favorit dan juga berkarir setelah lulus SMA. Pihak sekolah menyambut baik apabila kegiatan ini dapat dilaksanakan secara rutin untuk membekali siswa - siswi kelas XII dalam pematangan karir baik dilakukan secara online ataupun offline. Apabila wabah pandemic Covid-19 sudah berakhir, maka pihak sekolah bersedia berkolaborasi untuk membuat Karier Corner.

\section{Daftar Pustaka}

[1] Aji, R.H.S. (2020). Dampak Covid-19 pada Pendidikan Indonesia: Sekolah, Keterampilan, dan Proses Pembelajaran. Jurnal SALAM: Jurnal Sosial dan Budaya Syar-i FSH UIN Syarif Hidayatullah, Vol.7 (5), Mei 2020 (395-402).

[2] Suherman, U. (2013). Konseling Karir Sepanjang Rentang Kehidupan. Bandung: Sekolah Pascasarjana UPI 
[3] Hadiarni, (2009). Konseling Karier. Sumatera Barat: STAIN Batusangkar Press

[4] Connolly, T. \& Stansfield, M. (2006). Using Games-Based eLearning Technologies in Overcoming Difficulties in Teaching Information Systems. Journal of Information Technology Education, 6, 459-476. Diakses dalam http://www.jite.org/document/vol5/v5p459-476.Connolly170.pdf, 25 September 2020.

[5] Departemen Pendidikan Nasional. (2004). Peningkatan Kualitas Pembelajaran. Jakarta: Dit. P2TK dan KPT, Ditjen. Dikti, Depdiknas.

[6] Anderson, K. (2006). Using Online Discussions to Provide an Authentic Learning Experience for Professional Recordkeepers. Dalam Tony Herrington \& Jan Herrington, Authentic Learning Environment in Higher Education, Hershey, PA: Information Science Publishing. Hal. 214-223. 